\title{
AN INNOVATIVE METHOD OF THERMAL CONTACT HEATING AND MELTING OF HYDROCARBON MIXTURES TO OBTAIN SOFT DOSAGE FORMS
}

\section{ІННОВАЦІЙНИЙ МЕТОД ТЕРМОКОНТАКТНОГО НАГРІВАННЯ ТА ПЛАВЛЕННЯ ВУГЛЕВОДНЕВИХ СУМІШЕЙ ДЛЯ ОДЕРЖАННЯ М'ЯКИХ ЛІКАРСЬКИХ ФОРМ}

\section{Oleksandr Obodovych ${ }^{1}$ Olesya Stepanova ${ }^{2}$}

DOI: https://doi.org/10.30525/978-9934-26-001-8-2-7

Abstract. Heat exchange processes are of great importance for the implementation of technological operations in many industries, including the pharmaceutical, food and refining industries. The problem of heat transfer intensification is especially important for the creation of highenergy-efficient equipment. Heat-exchange processes of heating and melting are labor-intensive and energy-consuming, where it is necessary to transfer substances or mixtures from a solid state to a sufficiently fluid one to ensure their further transportation to the next stages of production. The peculiarity of hydrocarbon mixtures lies in their thermophysical properties: a wide range of changes in the phase transition temperature or melting point $\left(37 \ldots 100{ }^{\circ} \mathrm{C}\right)$, a tendency to thermal destruction and a low thermal conductivity $(0.034 \ldots 0.34 \mathrm{~W} / \mathrm{m} \cdot \mathrm{K})$. Traditionally, reactors with different mixer designs, baths with coils, electric tissue heaters, heating chambers, etc. are used at enterprises for heating and melting hydrocarbon mixtures. Mostly equipment is purchased abroad, for the purchase of which a lot of money is spent. Such methods are long and energy-intensive, there are large temperature gradients, which often leads to overheating of one part

\footnotetext{
${ }^{1}$ Doctor of Engineering Science, Senior Researcher,

Chief Researcher of Department Thermophysics of Pulsed Processes in Disperse Systems, Institute of Engineering Thermophysics of National Academy of Sciences of Ukraine, Ukraine ${ }^{2}$ Senior Researcher of Department Thermophysics of Pulsed Processes in Disperse Systems, Institute of Engineering Thermophysics of National Academy of Sciences of Ukraine, Ukraine
} 
of the substance and underheating of another. In addition, the process of loading mixtures into boilers and their subsequent unloading is problematic and contaminatingly dangerous. Given all this, the development and implementation of domestic innovative technologies and equipment for the processes of heating and melting of hydrocarbon mixtures is an urgent task.

\section{1. Вступ}

М'які лікарські форми (МЛФ) являють собою одну 3 найстародавніших лікарських форм, які не втратили своєї значущості і сьогодні у фармацевтичній промисловості та сучасній медицині.

Досить важливо, що м'які лікарські форми такі як мазі, лініменти, пасти і супозиторії являють собою саму оптимальну лікарську форму, в якій можна поєднувати компоненти, різні за хімічною природою, агрегатним станом, призначенням, біологічною активністю. Це пояснюється тим, що у в'язкому середовищі фізико-хімічні процеси (гідроліз, окислення та ін.) протікають значно повільніше. До всього вище сказаного можна додати, що сучасні кремові, мазеві і гелеві основи дозволяють вивільняти діючі речовини протягом $16 \ldots 18$ годин. А це висока ефективність і мінімальна кратність застосування, а значить - безпека, зручність у застосуванні і використанні [1].

Для забезпечення високої якості МЛФ у фармацевтичній та косметичній галузях промисловості при їх виробництві однією із задач $є$ підготовка основи, а саме нагрівання та плавлення в'язких вуглеводневих сумішей. що складаються 3 простої або складної мазевої основи. В якості таких основ виступають вазелін, парафін, ланолін, тверді жири та ін. Прості або складні мазеві основи, в яких зазвичай розчинені або дисперговані одна або більше діючих речовин, представляють собою в'язкі багатокомпонентні вуглеводневі суміші, для яких температура плавлення змінюється в широкому діапазоні $\left(27 \ldots 100^{\circ} \mathrm{C}\right)$. Отже, для кожної основи потрібно підібрати оптимальні параметри процесу плавлення, щоб не допустити перегріву, зміни властивостей основи та забезпечити мінімальні витрати енергії при переведенні речовини або суміші з твердого стану до достатньо плинного, щоб забезпечити їх подальше транспортування до наступних стадій виробництва.

Традиційно для проведення процесів нагрівання та плавлення використовуються реактори, ванни, електротканні нагрівачі, камери 
нагріву тощо. Такі методи мають ряд суттєвих недоліків: тривалість, трудомісткість і енергозатратність; можливість перегріву суміші, що призводить до різних змін фізико-хімічних та структурно-механічних властивостей продукту; можливість контамінації; нерівномірний прогрів всієї маси суміші. Часто ємності з такими мазевими основами містяться в неопалюваних або погано опалюваних приміщеннях (складах, цехах і т.д.) та є надто в'язкими для їх вивантаження 3 тари і транспортування в реактори-змішувачі. А враховуючи низькі коефіцієнти теплопровідності таких основ, все це ускладнює та уповільнює їх розплавлення. Подібні проблеми виникають i в харчовій промисловості при розплавленні жирів та олій [2], а також у нафтопереробній промисловості $є$ також проблеми, пов'язані 3 обігрівом залізничних цистерн, розплавленням і зливом 3 них нафтопродуктів [3].

Враховуючи вищенаведене, актуальною задачею $\epsilon$ апаратурнотехнічне переоснащення діючих виробництв, створення нових виробничих потужностей у зазначених галузях промисловості.

У фармацевтичному виробництві частіше доводиться готувати комбіновані м'які лікарські форми (МЛФ), які містять компоненти, розчинні або нерозчинні в основі або у воді. Все це обумовлює технологію отримання мазей i застосовану апаратуру. Відмінними особливостями виробництва МЛФ в заводських умовах $є$ те, що їх готують у спеціальних цехах із застосуванням складного устаткування за технологіями, які забезпечують їх стабільність не менше двох років, відповідно до розробленої та затвердженої нормативно-технічної документації НТД.

Виробництво МЛФ сконцентровано на фармацевтичних фабриках або великих хіміко-фармацевтичних заводах. У заводському виробництві м'яких лікарських форм використовується широкий асортимент основ і складне спеціальне обладнання. У технології МЛФ важливими є такі фактори: ступінь дисперсності лікарських речовин, вибір сплавлених компонентів основи, спосіб введення лікарських речовин в основу, час, швидкість та порядок змішування компонентів, температурний режим та інші параметри. Вони впливають на консистенцію, реологічні властивості, однорідність, стабільність при зберіганні та фармакотерапевтичну ефективність мазей [4]. 
Технологічний процес виробництва МЛФнахіміко-фармацевтичних підприємствах складається із таких основних стадій: санітарна обробка виробництва; підготовка сировини і матеріалів (лікарських речовин, основи, упаковки тощо); введення лікарських речовин в основу; гомогенізація мазей; стандартизація готового продукту; фасування, маркування та упаковка готової продукції.

\section{2. Основи для виготовлення м'яких лікарських форм}

Сьогодні на ринку є велика кількість лікарських препаратів, у тому числі лікарські форми 3 пластично-пружно-в'язким середовищем (близько 400 найменувань). 76 \% цих ліків є імпортними і тільки $24 \%$ - вітчизняного виробництва.

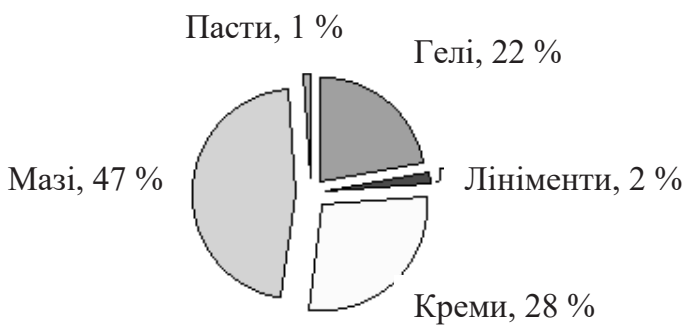

\section{Рис. 1. Асортимент м'яких лікарських форм на фармацевтичному ринку [5]}

На рис. 2 показані процеси, що досліджуються у роботі (нагрівання та плавлення вуглеводневих сумішей), при використанні в багатьох галузях промисловості для виробництва необхідних продуктів.

Як зазначалось, важливою стадією в технології компонентів вуглеводневої суміші основи. В залежності від фармакологічної дії МЛФ застосовуються гідрофобні, гідрофільні основи та їх суміші. Значення і роль основ в технології виробництва МЛФ важливі i різноманітні. Основи забезпечують необхідну масу мазей і відповідно належну концентрацію лікарських речовин, м'яку консистенцію, істотно впливають на їх стабільність. Ступінь вивільнення лікарських речовин з мазей, швидкість і повнота їх всмоктування багато в чому залежать від природи, складу і властивостей основи. 


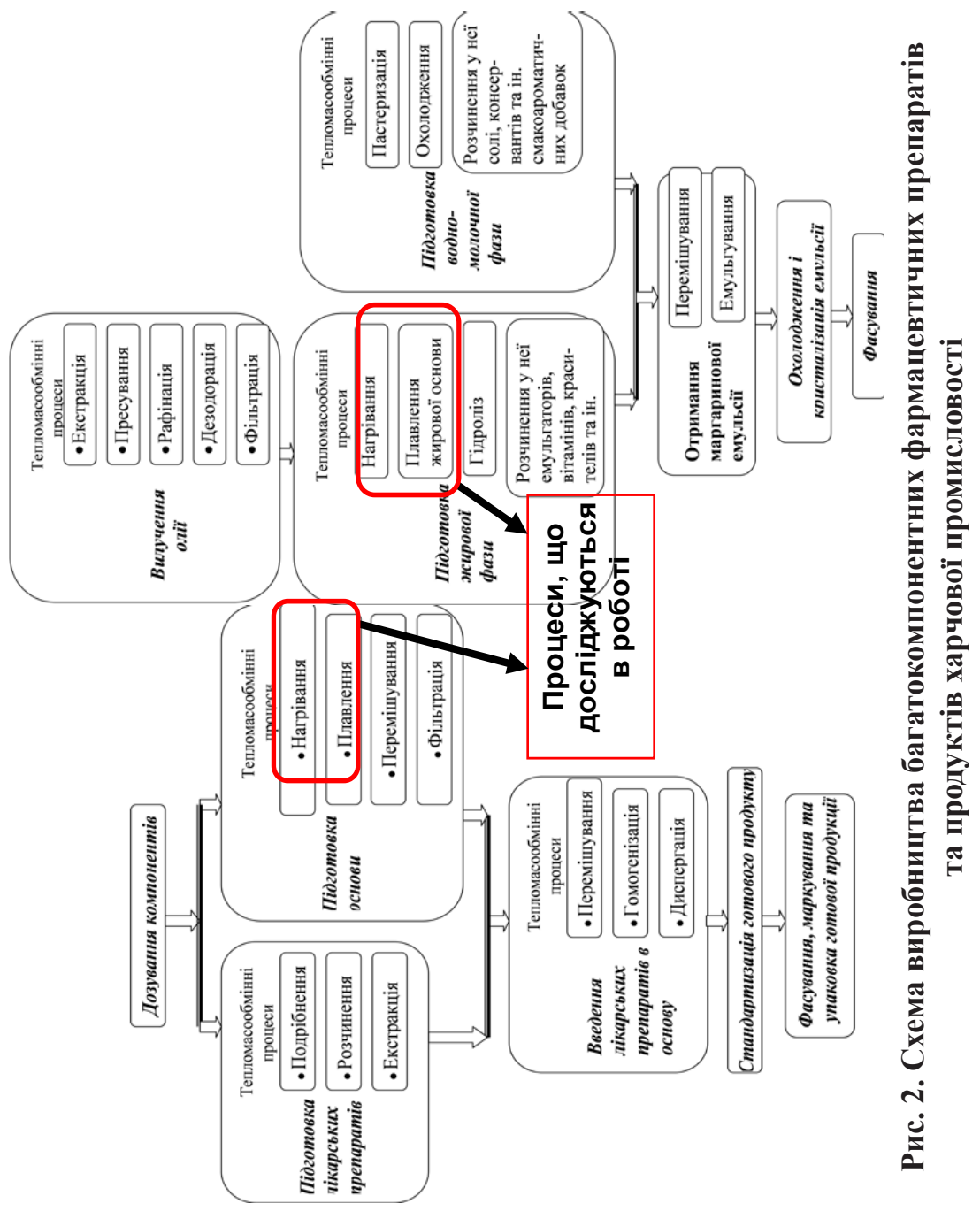


Реологічні параметри основ лікарських форм (ЛФ) та їх сумішей 3 допоміжними речовинами, що застосовують у виробництві МЛФ, важливі при виборі виробничого обладнання, необхідного для виконання того або іншого технологічного процесу (плавлення, змішування, гомогенізації, диспергування).

Теплофізичні властивості деяких вуглеводневих сумішей, теплоносія та матеріалу термоконтактної поверхні представлені в таблиці 1.

Аналіз літературних джерел показав, що традиційні способи розплавлення основ для МЛФ за допомогою реакторів, ванн, електротканних нагрівачів, камер нагрівутаін.частоєенергозатратними, трудомісткими та контамінаційно небезпечними. Наприклад, спосіб плавлення, що реалізуються за допомогою нагрівальних елементів [6, 7], які розташовуються на зовнішній поверхні ємності і обігрівають основу через іiі стінку дозволяє створити рівномірний тепловий потік по всій висоті ємності, але при такому способі плавлення через стінки металевої ємності швидкість переміщення фронту плавлення в об'ємі мала через низьку теплопровідність основ, що призводить до розплавлення основи біля стінок ємності (можливість виникнення деструкції основи від перегріву стінок ємності), а в середині речовина залишається нерозплавленою (рис. 3).

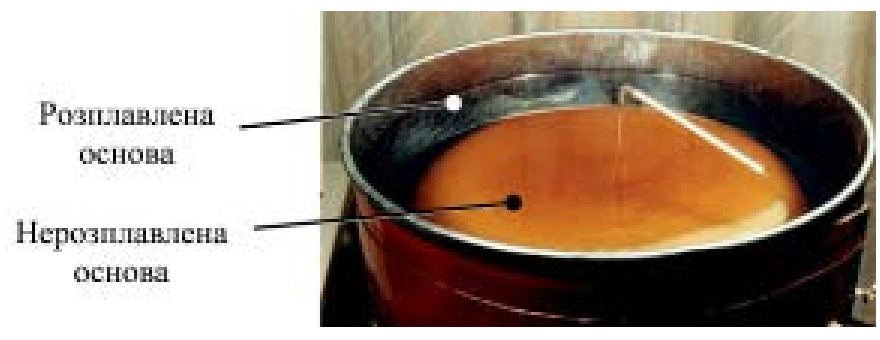

\section{Рис. 3. Процес плавлення вазеліну в ємності з використанням нагрівальних елементів, розташованих на зовнішній поверхні смності [8]}

В Україні до сих пір використовуються вітчизняні установки (рис. 4), що представляють собою ванну, в якій знаходиться змійовик для пара, решітка з соплами, продуктовий насос та механізм для 
Oleksandr Obodovych, Olesya Stepanova

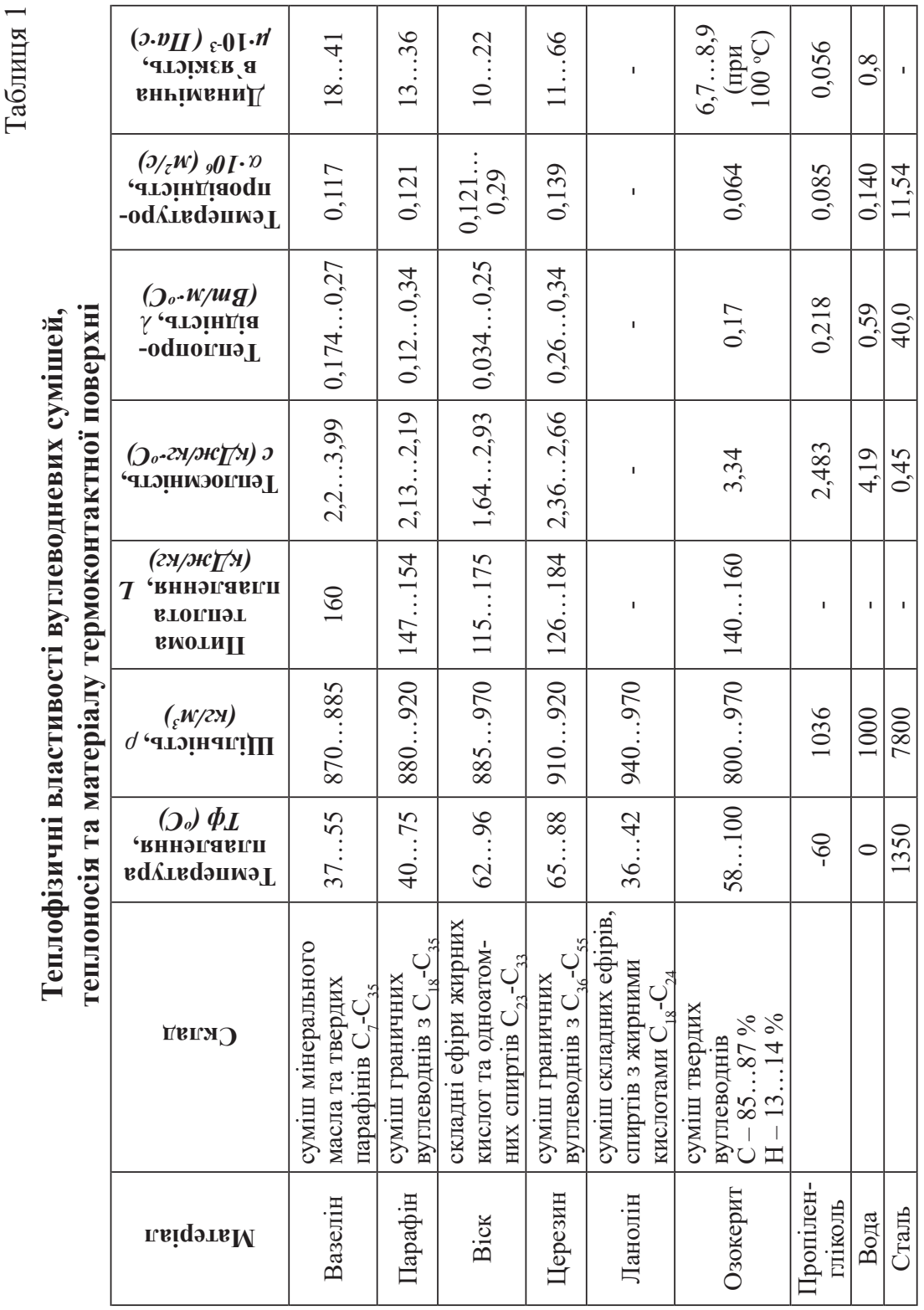


перекидання бочки. Частина речовини вручну завантажується у ванну, в якій плавиться за допомогою перегрітого пару у змійовику. Ємність 3 речовиною за допомогою механізму для перекидання перевертається та ставиться на сопла. Продуктовим насосом в сопла подається розплав речовини і розмиває її у ємності.

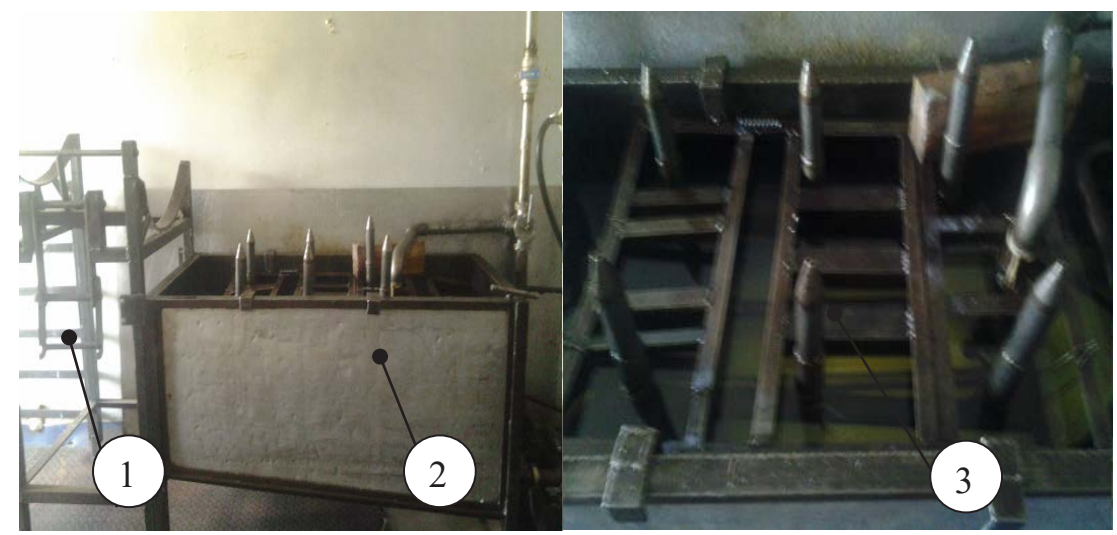

Рис. 4. Вітчизняна установка для нагрівання і плавлення:

1 - механізм для перекидання ємності; 2 - змійовик для пара; 3 - решітка $з$ соплами

Суттєвими недоліками такої установки є не відповідність вимогам до правил належної практики виробництва (GMP) для фармацевтичної промисловості, нерівномірний прогрів всієї маси вуглеводневої суміші, трудомісткий, бо потребує ручного завантаження речовини та контамінаційна небезпечність.

Реактори та ванни на даний час витісняються плоскими силіконовими, міканітовими (слюдяними) нагрівачами та обігрівачами у вигляді оболонки, яка повністю покриває ємність, що знайшли широке застосування на підприємствах, що займаються виготовленням кремів, косметики для розплавлення воску, вазеліну, жирів і інших речовин. Ці способи зараз $є$ найбільш простим рішенням для нагріву речовин, що зберігаються в металевих або пластикових бочках.

В Інституті технічної теплофізики розроблений спосіб термоконтактного плавлення за рахунок контактного та конвективного 
переносу тепла [9], що дозволяє інтенсифікувати процес і зменшити енерговитрати. Спосіб плавлення основи МЛФ, розміщеної в циліндричній ємності, грунтується на русі дискового нагрівального елемента під дією сили тяжіння в процесі плавлення і перетікання розплавленої основи через зазори між диском і стінками ємності. Відмінність запропонованого способу від існуючих полягає в підведенні енергії безпосередньо до фронту фазового перетворення за допомогою дискового нагрівального елемента, який контактує із зовнішньою границею нерозплавленої речовини. Спосіб дозволяє нагрівати та розплавляти лише ту частину основи, яка необхідна, тобто реалізовувати дозований процес плавлення, що дає можливість більш раціонально використовувати енергію. При цьому температуру дискового нагрівача в зоні контакту з основою підтримують нижчою температури її деструкції. В товщі розплаву підтримання температури плавлення відбувається за рахунок конвективної теплопередачі від верхньої поверхні нагрівача.

\section{3. Стенд для проведення процесів нагрівання та плавлення}

На основі цього способу з метою вивчення процесів нагрівання та плавлення вуглеводневих сумішей в Інституті технічної теплофізики НАН України було виготовлено стенд (рис. 5, 6), який працює 3 використанням метода локального термоконтактного нагріву [10]. Стенд складається 3 ємності 3 речовиною, дискового нагрівача, який безпосередньо контактує з системою і розплавляє їі поступово опускаючись до низу ємності з можливістю додавання навантаження на нагрівач. Також до стенду входить регулятор напруги та тиску. Дисковий нагрівач було оснащено трьома термопарами типу хромелькопель, дві з яких знаходяться знизу нагрівача ДТ1 та ДТ2, а третя зверху на нагрівачі ДТ3, показання яких оброблювалися аналоговоцифровим перетворювачем і виводились на комп'ютер. Додатково оброблювалися показання з термопари ДТ4, яка вимірює температуру оточуючого середовища. На цьому стенді була проведена серія дослідів, в якості модельного тіла використовувався вазелін.

Порядок проведення роботи на «Стенді для експериментального дослідження процесів нагрівання та плавлення вуглеводневих систем» був наступним: 
- увімкнути аналогово-цифровий перетворювач та зачекати поки покази температури не зрівняються 3 температурою оточуючого середовища;

- опустити дисковий нагрівач зверху в ємність до контакту його 3 в'язкою системою;

- увімкнути головний вмикач на регуляторі напруги та струму стенду;

- задати необхідну напругу;

- проводити процес плавлення в'язкої вуглеводневої системи доки дисковий нагрівач не опуститься до низу ємності;

- результати показів термопар обробляють за допомогою програми DASYLab 10.0 на ПК;

- зберегти отримані графіки результатів дослідів.

На рис. 7 показаний процес плавлення вазеліну на експериментальному стенді по мірі руху нагрівача і розплавлення вазеліну.

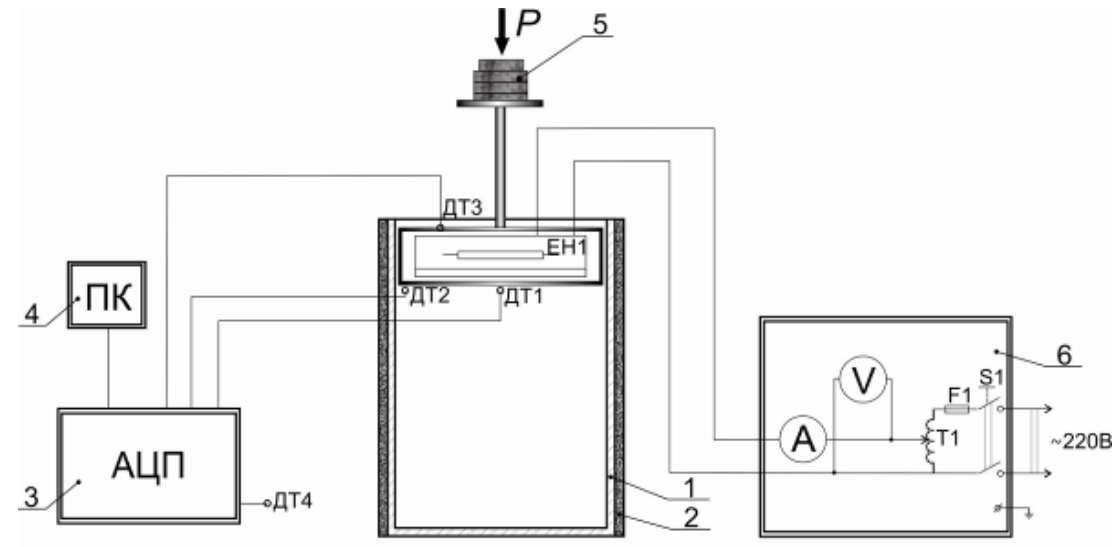

Рис. 5. Принципова схема стенда для експериментального дослідження процесів нагрівання та плавлення вуглеводневих

сумішей: 1 - смність 3 речовиною; 2 - ізоляція ємності;

3 - аналогово-цифровий перетворювач; 4 - персональний комп'ютер; 5 - тягар; 6 - регулятор напруги;

ДТ1...ДТ4 - датчики температури; ЕН1 - електричний нагрівач;

T1 - трансформатор; F1 - запобіжник; S1 - вимикач 


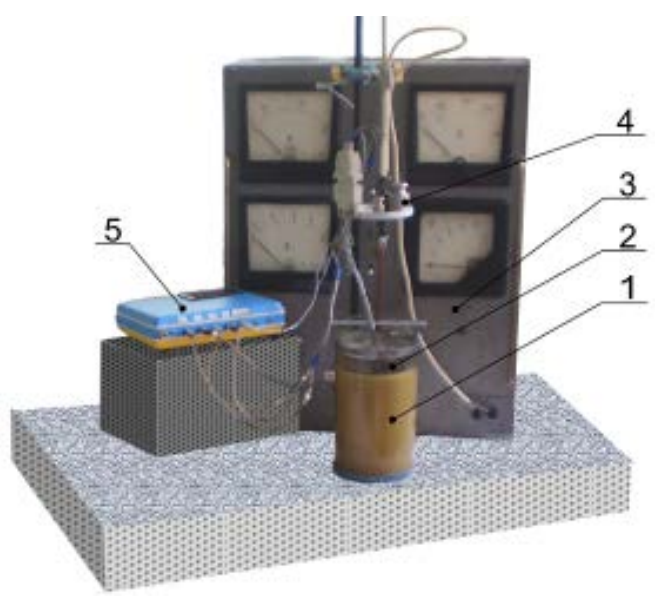

Рис. 6. Загальний вигляд стенда для експериментального дослідження процесів нагрівання та плавлення вуглеводневих сумішей: 1 - смність 3 речовиною;

2 - електричний нагрівач; 3 - регулятор напруги;

4 - тягар; 5 - аналогово-цифровий перетворювач
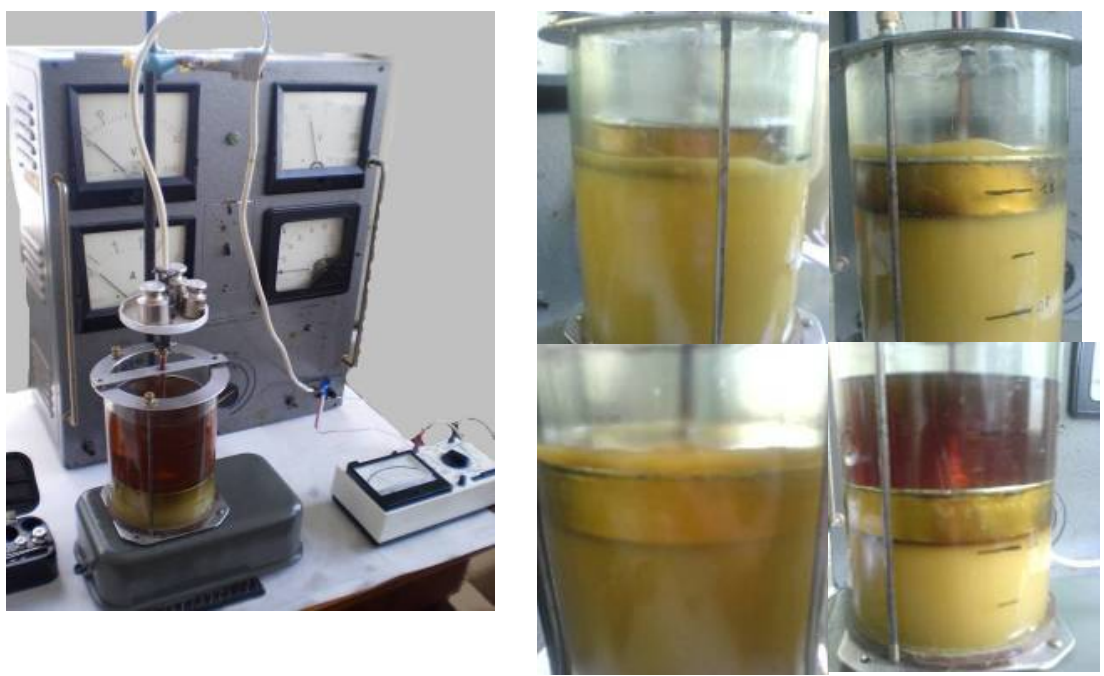

Рис. 7. Процес плавлення вазеліну на експериментальному стенді 
Вивід результатів досліджень на комп’ютер за допомогою аналоговоцифрового перетворювача представлений у вигляді (Т - t) діаграм (рис. 8).

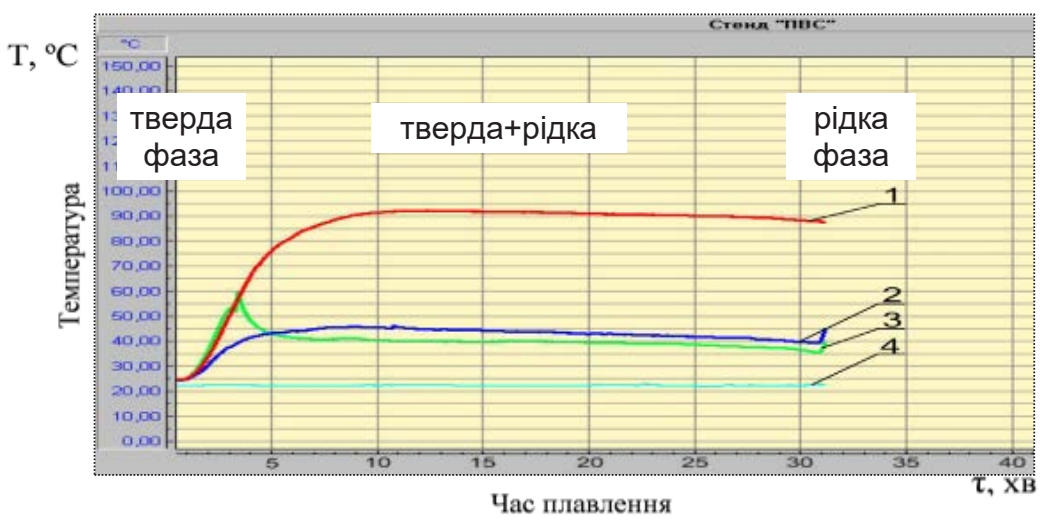

Рис. 8. Діаграма (T - t) плавлення вазеліну:

1 - температура нагрівача (ДТ3); 2,3 - температура розплаву під нагрівачем (ДТ1 та ДТ2); 4 - температура оточуючого середовища (ДТ4)

На лабораторному стенді проведені дослідження процесу нагрівання та плавлення. Як видно з отриманих графіків (рис. 9 та рис. 10), чим більша температура нагрівача та тиск на нагрівач, тим більша швидкість плавлення вазеліну $(0,032 \ldots 0,04$ кг/хв.).

\section{4. Установка для термоконтактного нагрівання та плавлення}

На основі запропонованого способу та проведених досліджень на лабораторному стенді розроблена установка для термоконтактного нагрівання та плавлення (рис. 11, 12) [11].

В установці об'єднані три технологічні операції: плавлення, вивантаження та дозування в одному технологічному циклі, що, окрім енергоефективності, дозволяє заощадити часові та людські ресурси.

Установка для плавлення речовин “ТЕРМОБАТ-М” складається 3 наступних вузлів (рис. 12): корпус 1 з вантажопідйомним механізмом і упором 5 для центрування бочки з продуктом; шафа електрокерування 2; електронагрівальний апарат 8. 


\section{Oleksandr Obodovych, Olesya Stepanova}

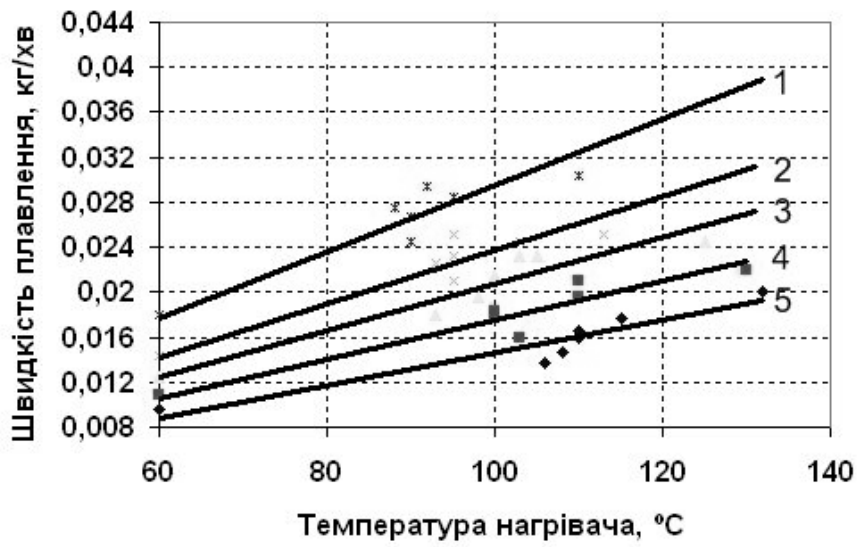

1 - $\mathrm{P}=0,8$ кПа; 2 - $\mathrm{P}=1$ кПа; 3 - $\mathrm{P}=1,4$ кПа; 4 - P=1,7 кПа; 5 - $\mathrm{P}=2$ кПа.

Рис. 9. Залежність швидкості плавлення вазеліну від температури нагрівача при різних тисках

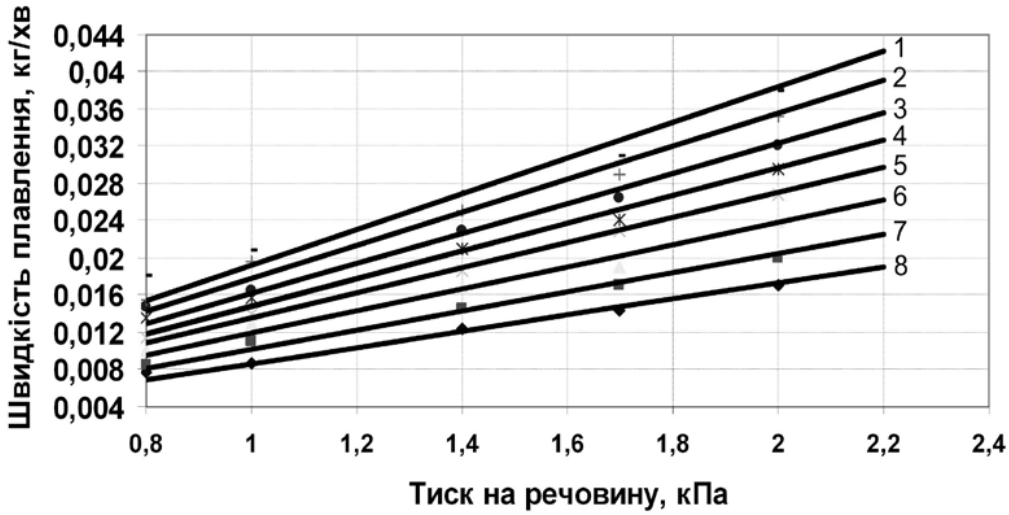

$1-\mathrm{T}=60^{\circ} \mathrm{C} ; \quad 2-\mathrm{T}=70^{\circ} \mathrm{C} ; \quad 3-\mathrm{T}=80^{\circ} \mathrm{C} ; \quad 4-\mathrm{T}=90^{\circ} \mathrm{C}$;

$5-\mathrm{T}=100^{\circ} \mathrm{C} ; \quad 6-\mathrm{T}=110^{\circ} \mathrm{C} ; \quad 7-\mathrm{T}=120^{\circ} \mathrm{C} ; \quad 8-\mathrm{T}=130^{\circ} \mathrm{C}$.

Рис. 10. Залежність швидкості плавлення вазеліну від тиску при різних температурах нагрівача 


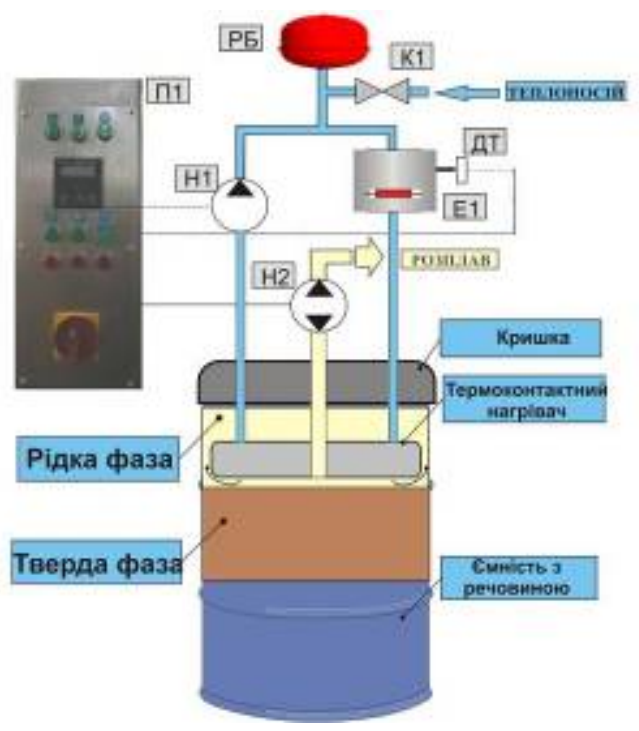

Рис. 11. Принципова схема установки для термоконтактного нагрівання та плавлення: Н1 - циркуляційний насос; Н2 - продуктовий насос; ДТ - датчик температури; РБ - розширювальний бачок;

П1 - пульт керування; К1 - запірна арматура контуру циркуляції теплоносія; E1 - електричний нагрівач

В корпусі 1 встановлений вантажопідйомний механізм для підйому та опускання електронагрівального апарату 8.

Вантажопідйомний механізм містить лебідку з ручкою 4 і перемикачем підйому/опускання 3 і тросом, з'єднаних через блоки 3 нижньою кареткою, над якою розташована верхня каретка. Каретки переміщаються по напрямних. На верхній каретці закріплений нагрівальний апарат 8.

Шафа електрокерування 2 містить пускорегулюючу апаратуру, цифровий вимірювальний прилад типу ТРЦ 02 Універсал $з$ дисплеєм цифрової індикації, кнопки управління. Це обладнання призначено для включення i виключення електронагрівача, циркуляційного i продуктового насосів, захисту електродвигунів установки і підтримки заданих температур нагрівального апарату. 


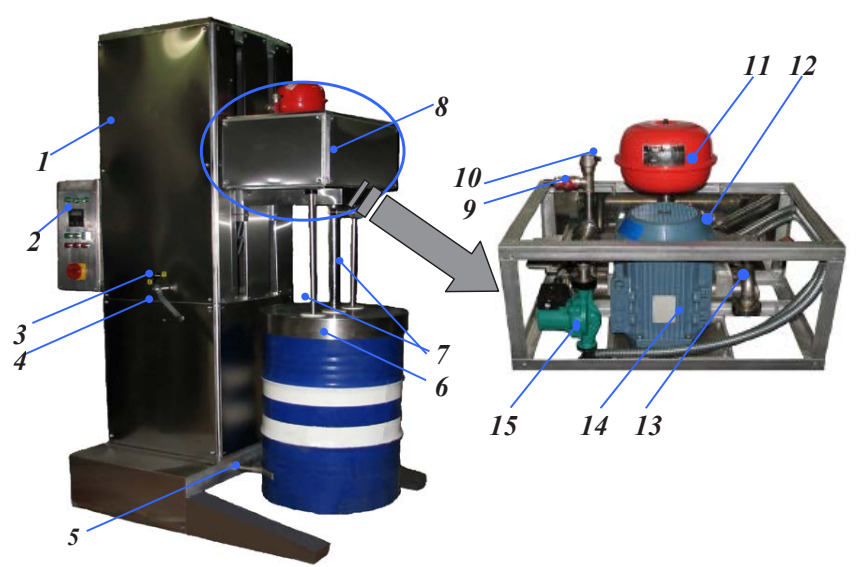

Рис. 12. Загальний вид установки для нагрівання та плавлення в'язких основ “Термобат-М":

1 - корпус 3 вантажопідйомним механізмом; 2 - шафа електроуправління; 3 - перемикач вантажопідйомного механізму;

4 - ручка лебідки; 5 - упор; 6 - термоконтактний нагрівач 3 кришкою; 7 - трубопровід теплоносія; 8 - електронагрівальний апарат; 9 - штуцер для заливу теплоносія; 10 - повітревідводчик;

11 - розширювальний бачок; 12 - штуцер контролю переливу теплоносія; 13 - електрокотел; 14 - гвинтовий насос;

15 - циркуляційний насос

Нагрівальний апарат 8 призначений для нагріву термоконтактного нагрівача 6 і плавлення речовини, а також відбору розплаву із зони контакту. Термоконтактний нагрівач 6 апарату 8 занурюється в речовина при іï плавленні на задану глибину. Температура на поверхні розплаву підтримується вище температури плавлення речовини за рахунок конвективних потоків в розплаві.

Нагрівальний апарат 8 (рис. 13) містить:

- електричний проточний котел 13 з трубчастим електронагрівачем, розширювальним бачком 11 і циркуляційним насосом 15;

- термоконтактний нагрівач 6, виконаний у вигляді теплообмінника, з'єднаного двома паралельними трубами 7 з електричним котлом 13; 
- кришка установки, адаптована до бочки 3 продуктом, і має можливість переміщатися уздовж труб 7 підведення і відведення теплоносія;

- продуктовий насос 14 для відводу розплаву, при цьому вихідна труба виконана у вигляді гнучкого шланга закріплюється на штуцер. Продуктовий насос має режим реверсу. Насос відповідає вимогам GMP і має продуктивність при 750 об/хв. - 23 л/хв. (рис. 13).

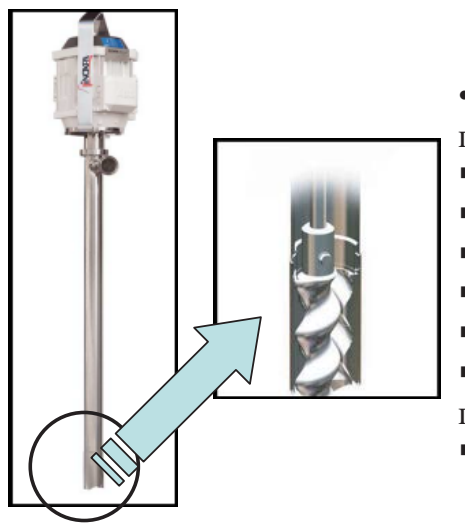

- Продуктивність:

при 750 об/хв......................23 л/хв

- Максимальний тиск.................6 бар

- Максимальна в'язкість........100 мПа·с

- Температура.............. $100^{\circ} \mathrm{C} \ldots+85^{\circ} \mathrm{C}$

- Рівень шуму................60...80 дБ(А)

- Діаметр корпусу насоса...........54 мм

- Деталі, що контактують 3

продуктом............................316L

- Інші деталі 3 нерж. сталі...................304

\section{Рис. 13. Гвинтовий насос KIBER RVB-25}

На основі проведених експериментальних досліджень методу термоконтактного нагрівання та плавлення на установці «Термобат-М» отримано графік залежності об’єму розплаву від температури нагрівача (рис. 14) для вибору оптимальних параметрів проведення процесу плавлення. Інтенсифікація процесу плавлення досягається збільшенням температури нагрівача, а також створенням однорідного температурного поля на поверхні термоконтактного нагрівача завдяки обраній конструкції [12].

При дослідженнях 3 використанням тепловізора марки Ti-160 вдалося простежити рух нагрівача по довжині ємності, а також розподілення температур на поверхні термоконтактного нагрівача та всередині металевих ємностей заводу-виробника (рис. 15). Термограми показують рівномірний прогрів термоконтактного нагрівача (рис. 15, а) та всього об'єму розплаву при його русі до низу ємності і плавлення 


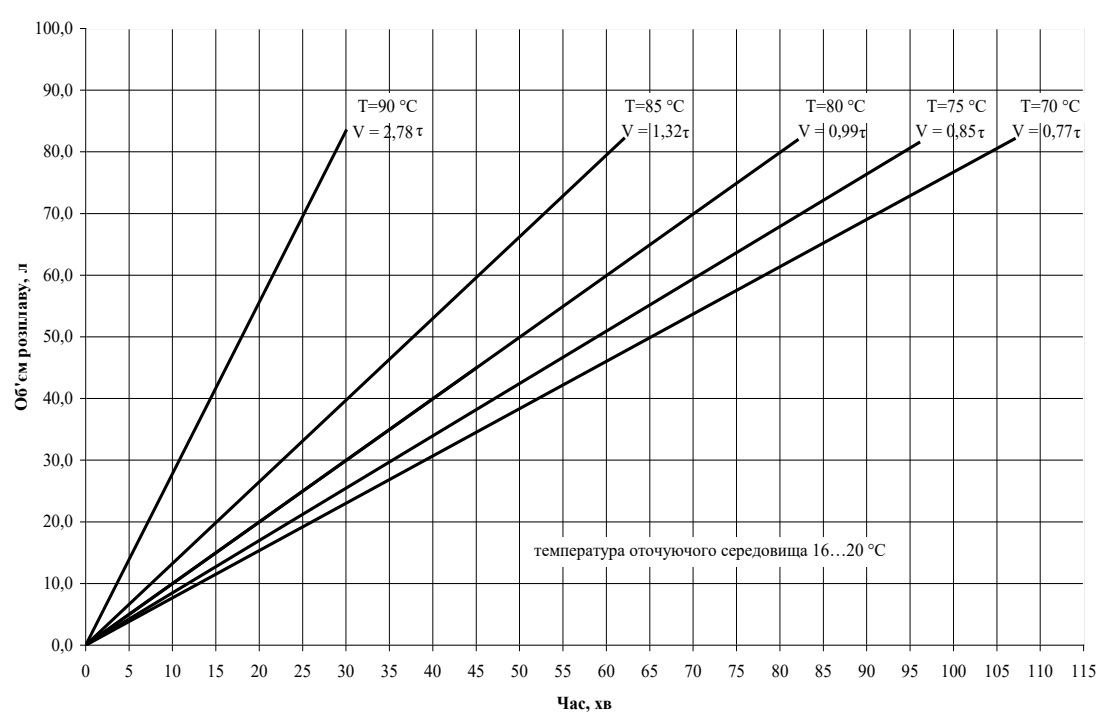

\section{Рис. 14. Графік залежності об'сму розплаву} від температури нагрівача

основи (рис. 15, б-г). Завдяки низькому коефіцієнту теплопровідності основ вона знаходиться у початковому в'язкому стані,а нагрівається та плавиться при контакті $з$ нагрівачем (рис. 15, в). Вкінці процесу (рис. 15, г) спостерігаються конвективні потоки, що сприяє підтриманню температури розплаву на заданому рівні [12].

Використання установки “Термобат-М” дозволяє в 1,2-1,7 разів скоротити витрати енергії у порівнянні з існуючими, таких як плавлення у нагрівальних камерах та жиротопках (рис. 16).

Розроблений спосіб та установка для термоконтактного нагрівання та плавлення дозволяє швидко та якісно розплавити необхідну кількість основи (рис. 17, 18) для транспортування на наступні стадії виготовлення м'яких лікарських форм. Установки типу “Термобат”, що відповідають стандартам GMP, розроблені та впроваджені на фармацевтичних фабриках: КП “Фармація” “Луганська фармацевтична фабрика”, м. Луганськ; АТ “Ризька фармацевтична фабрика”, м. Рига; ТОВ “Тернофарм”, м. Тернопіль. 


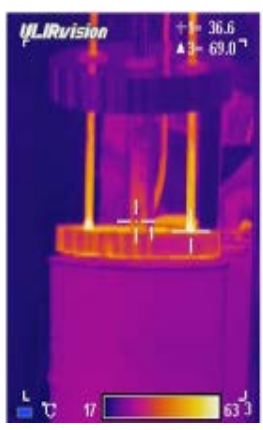

a)

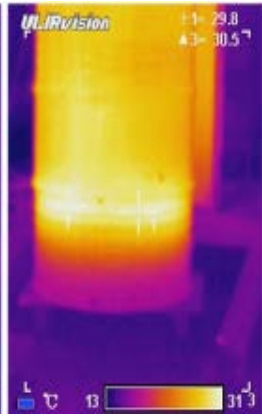

б)

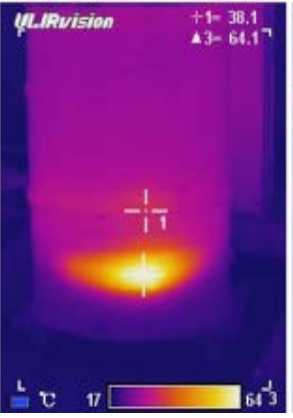

b)

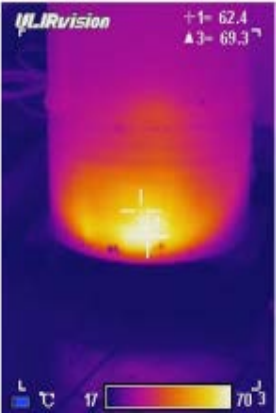

2)

Рис. 15. Термограми процесу термоконтактного нагрівання та плавлення основ в ємностях заводу-виробника:

a) прогрів термоконтактного нагрівача;

б) початок нагрівання та плавлення;

в) прогрів в процесі опускання термоконтактного нагрівача;

г) закінчення нагрівання та плавлення (термоконтактний нагрівач опустився на дно ємності).

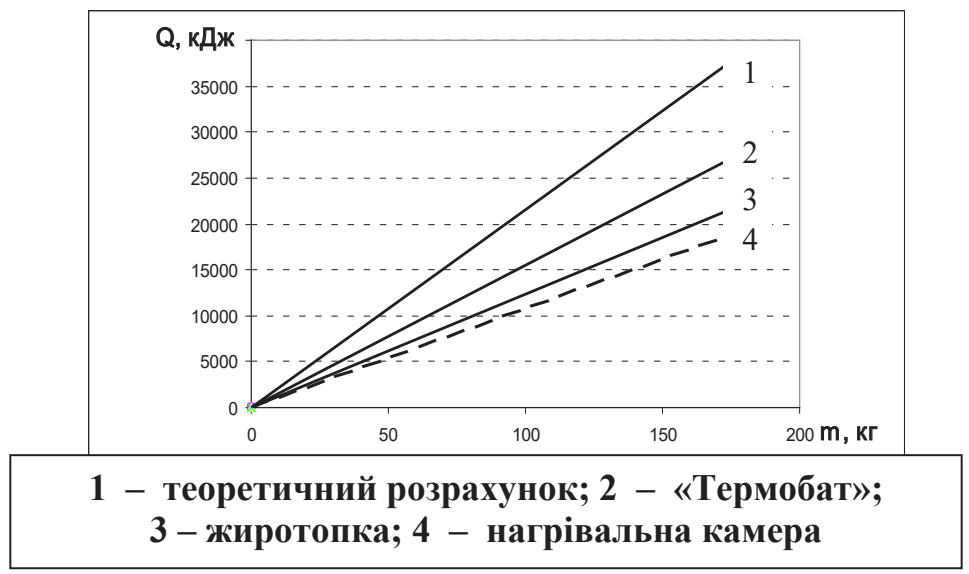

Рис. 16. Порівняння енергетичних витрат для різних методів плавлення 


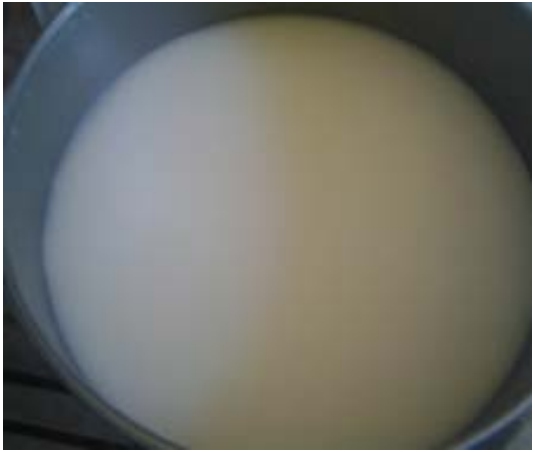

Рис. 17. Вазелін білий фармацевтичний MERKUR 500 (Германия)

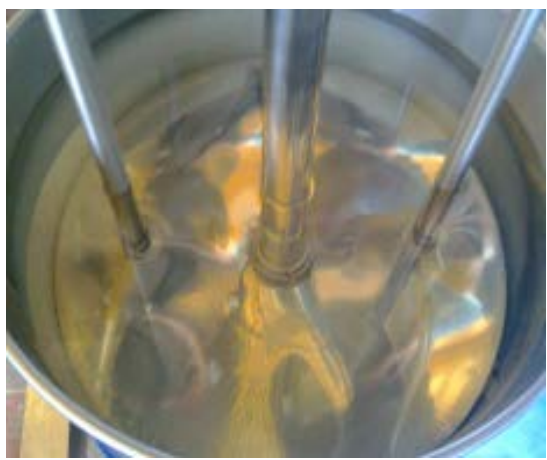

Рис. 18. Розплавлений вазелін на установці «Термобат-М»

Промислові випробування (рис. 19) установки “Термобат-М” проводились на ТОВ “Тернофарм”, м. Тернопіль при початковій температурі вазеліну $30^{\circ} \mathrm{C}$ та $13^{\circ} \mathrm{C}$ (температура теплоносія $90^{\circ} \mathrm{C}$, температура оточуючого середовища $\left.30^{\circ} \mathrm{C}\right)$.

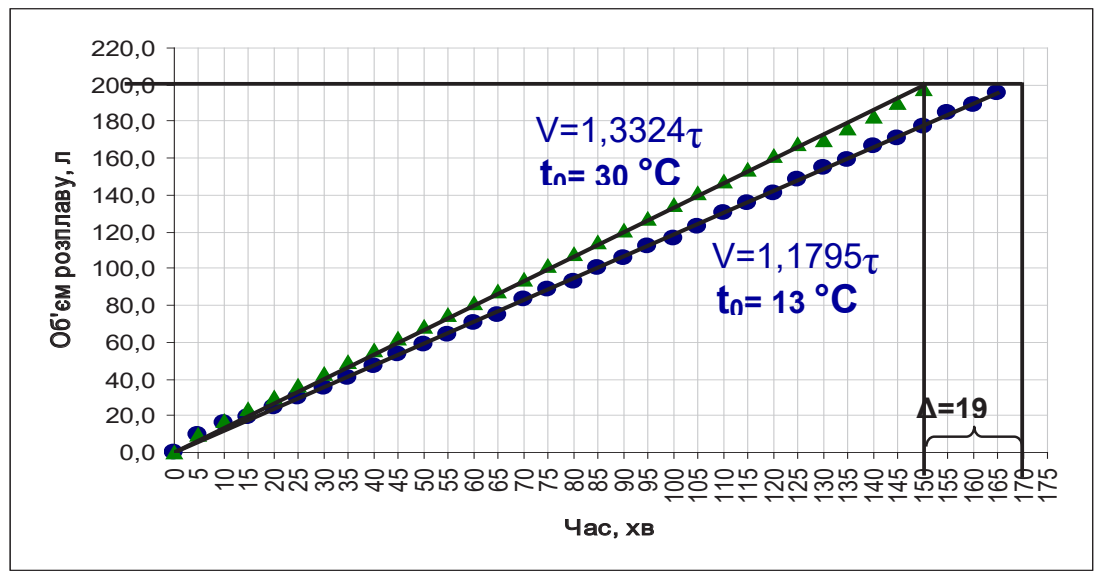

Рис. 19 Результати промислових випробувань на установці "Термобат-М" на ТОВ "Тернофарм", м. Тернопіль при початковій температурі вазеліну $30^{\circ} \mathrm{C}$ та $13^{\circ} \mathrm{C}$ 


\section{5. Висновки}

1. Проведений аналіз існуючих технологій та обладнання здійснення процесів нагрівання та плавлення вуглеводневих сумішей показав, що ці технології є тривалими, трудомісткими та енергоємними.

2. Проведені дослідження термоконтактного нагрівання та плавлення вуглеводневих сумішей на розробленому та виготовленому експериментальному стенді показує, що використання термоконтактного методу дозволяє створити рівномірне поле температур і провести процес плавлення з перегрівом не перевищуючим температури плавлення речовини на $5 \ldots 7^{\circ} \mathrm{C}$, інтенсифікувати процес та отримати високу якість кінцевого продукту.

3. На основі проведених досліджень розроблена та виготовлена установка для нагрівання та плавлення в'язких і низькотеплопровідних субстанцій «Термобат-М». Підготовлена вся технічна документація та кваліфікаційні документи для валідації по GMP.

4. При застосуванні термоконтактного методу нагріву за допомогою заглибного нагрівача можливо отримати необхідну кількість продукту, що плавиться, скоротити час отримання розплаву і зменшити енерговитрати.

5. Проведені випробування в ІТТФ НАНУ і заводські випробування на території ТОВ “Тернофарм” показують, що вдалося досягнути високої продуктивність установки (в залежності від температури нагріву становить $52 \ldots 83$ л/год). По результатам заводських випробувань установка “Термобат-М” передана в експлуатацію на ТОВ “Тернофарм" в м. Тернопіль (Акт впровадження від 9 липня 2014 року).

\section{Список літератури:}

1. Тихонов О.І., Ярних Т.Г., Лукієнко О.В. та ін. М'які лікарські форми: Екстемпоральна рецептура: Методичні рекомендації / За ред. О.І. Тихонова. Харків : Вид-во НФаУ; Золоті сторінки, 2003. 128 с.

2. Глущенко О.М., Полова 3.М. Аналіз ринку м'яких лікарських засобів, що сприяють загоєнню ран. Фармачевтичний часопис. 2019. № 4. С. 51-56. DOI: https://doi.org/10.11603/2312-0967.2019.4.10684

3. Грабов Л.М., Посунько Д.В., Степанова О.С., Базєєв Р.С. Енергозбереження при термоконтактному плавленні жирів. Наукові праиі Одеської національної академії харчових технологій. 2012. Т. 2, вип. 41. С. 50-55.

4. Грабов Л.Н., Степанова О.Е. Использование метода ДИВЭ для нагревания и сбора разлитой нефти. Наукові праџі Одеської національної академії харчових технологій. 2014. Т. 3, вип. 45. С. 152-155. 
5. Чуешов В.И., Гладух Е.В., Ляпунова О.А., Сайко И.В., Сичкарь А.А., Рубан Е.А., Крутских Т.В. Промышленная технология лекарств : электронный учеб. Харьков, 2010. URL: http://ztl.pp.ua/html/medication/index.html

6. Сайт корпорації "BRISKHEAT". URL: http://www.briskheat.com/

7. Сайт корпорації "Fabtech Technologies International Pvt. Ltd.". URL: http://www.fabtechnologies.com/

8. Долінський А.А., Грабов Л.М., Степанова О.Є. Теплообмін при нагріванні і плавленні основ для виготовлення косметичних та фармацевтичних препаратів. Промыиленная теплотехніка. 2011. Т. 33, № 3. С. 5-12.

9. Грабов Л.М., Мерщій В.І., Бондарь С.I. «Спосіб плавлення речовини та пристрій для його здійснення», Патент України 31435, 17 грудня, 2001.

10. Грабов Л.М., Степанова О.С., Базєєв Р.С. Експериментальні дослідження процесів нагрівання та плавлення вуглеводневих систем. Промышленная теплотехника. 2013. Т. 35, № 3. С. 13-20.

11. Oleksii Shmatok Innovative method and installation for heating and melting bases for the production of suppositories / Oleksii Shmatok, Stepanova Olesya, Rostislav Bazeev // Proceedings of the 2nd International Scientific Conference "Chemical Technology and Engineering - 2", June 24-28th, Lviv. 2019. P. $160-163$.

12. Шматок А.И., Степанова О.Е., Сильнягина Н.Б. Инновационная технология и оборудование для получения суппозиториев. Наукові пращі Одеської національної академії харчових технологій. 2019. вип. 1, Т. 83. С. 57-61. DOI: 10.15673/swonaft.v83i1.1418

\section{References:}

1. Tykhonov O.I., Jarnykh T.Gh., Lukijenko O.V. ta in. (2003). M'jaki likarsjki formy: Ekstemporaljna receptura: Metodychni rekomendaciji [Mild dosage forms: Extemporaneous formulation: Guidelines]. Kharkiv NUPh Publishing House; Golden pages, $128 \mathrm{p}$.

2. Ghrabov L.M., Posunjko D.V., Stepanova O.Je., Bazjejev R.Je. (2012). Energhozberezhennja pry termokontaktnomu plavlenni zhyriv [Energy saving during thermal contact melting of fats]. Scientific works of the Odessa National Academy of Food Technologies, vol. 2, issues 41, pp. 50-55.

3. Grabov L.N., Stepanova O.E. (2014). Ispol'zovanie metoda DIVE dlya nagrevaniya i sbora razlitoy nefti [Using the DPIE method for heating and collecting spilled oil]. Scientific works of the Odessa National Academy of Food Technologies, vol. 3, issues 45, pp. 152-155.

4. Chueshov V.I., Gladukh E.V., Lyapunova O.A., Sayko I.V., Sichkar' A.A., Ruban E.A., Krutskikh T.V. (2010). Promyshlennaya tekhnologiya lekarstv: elektronnyy ucheb. [Industrial technology of drugs: electronic textbook]. Kharkov. Retrieved from: http://ztl.pp.ua/html/medication/index.html

5. Glushchenko O.M., Polova Z.M. (2019). Analiz rynku miakykh likarskykh zasobiv, shcho spryiaiut zahoienniu ran. Farmatsevtychnyi chasopys, no. 4, pp. 51-56. DOI: https://doi.org/10.11603/2312-0967.2019.4.10684 
6. Sajt korporaciji "BRISKHEAT" [BRISKHEAT Corporation Website]. Retrieved from: http://www.briskheat.com/

7. Sajt korporaciji "Fabtech Technologies International Pvt. Ltd." [Website of Fabtech Technologies International Pvt. Ltd.]. Retrieved from: http://www.fabtechnologies.com/

8. Dolinsjkyj A.A., Ghrabov L.M., Stepanova O.Je. (2011). Teploobmin pry naghrivanni i plavlenni osnov dlja vyghotovlennja kosmetychnykh ta farmacevtychnykh preparativ [Heat transfer during heating and melting of bases for the manufacture of cosmetics and pharmaceuticals]. Industrial heat engineering, vol. 33, no. 3, pp. 5-12.

9. Ghrabov L.M., Mershhij V.I., Bondarj S.I. (2001). Sposib plavlennja rechovyny ta prystrij dlja jogho zdijsnennja [The method of melting a substance and a device for its implementation], Pat. UA 31435.

10.Ghrabov L.M., Stepanova O.Je., Bazjejev R.Je. (2013). Eksperymentaljni doslidzhennja procesiv naghrivannja ta plavlennja vughlevodnevykh system [Experimental studies of the processes of heating and melting of hydrocarbon systems]. Industrial heat engineering, vol. 35, no. 3, pp. 13-20.

11. Oleksii Shmatok, Stepanova Olesya, Rostislav Bazeev (2019). Innovative method and installation for heating and melting bases for the production of suppositories // Proceedings of the 2nd International Scientific Conference "Chemical Technology and Engineering - 2", June 24-28th, Lviv. Pp. 160-163.

12. Shmatok O.I., Stepanova O.E., Sil'nyagina N.B. (2019). Innovatsionnaya tekhnologiya i oborudovanie dlya polucheniya suppozitoriev [Innovative technology and equipment for producing suppositories]. Scientific works of the Odessa National Academy of Food Technologies, issues 1, vol. 83, pp. 57-61. DOI: $10.15673 /$ swonaft.v83i1.1418 